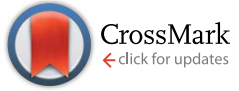

Cite this: RSC Adv., 2017, 7, 12224

Received 26th December 2016 Accepted 14th February 2017

DOI: $10.1039 / c 6 r a 28683 f$

rsc.li/rsc-advances

\section{Fabrication of $\mathrm{SiO}_{2}$ asilicalite-1 and its use as a catalyst support}

\begin{abstract}
Xiaobing Yang, Liuqing Huang, Jintang Li, Xueyuan Tang and Xuetao Luo*
$\mathrm{SiO}_{2}$ (asilicalite-1, using silica sol ( $\mathrm{pH}=9.47, \mathrm{SiO}_{2} \approx 30 \mathrm{wt} \%$ ) as the silica source, was directly synthesized in a eutectic mixture where silicalite-1 grains were formed in the three-dimensional net structure of silica gel, grown in situ by transforming amorphous $\mathrm{SiO}_{2}$ into an MFI-type structure and coated with amorphous $\mathrm{SiO}_{2}$. The alkalinity, template agent, and crystallization time strongly affect the physicochemical properties of $\mathrm{SiO}_{2}$ (asilicalite-1. The physicochemical properties of these samples were characterized by scanning electron microscopy (SEM), X-ray diffraction (XRD), transmission electron microscopy (TEM), UV-vis diffuse reflectance spectra and nitrogen adsorption. The results show that the $\mathrm{SiO}_{2}$ (asilicalite-1 is synthesized in a eutectic mixture and its physicochemical properties can be tuned by controlling the content of sodium hydroxide and tetrapropyl ammonium bromide (TPABr). A time-dependent study reveals that the formation process obeys an in situ epitaxial growth and phase transformation mechanism. Finally, $\mathrm{SiO}_{2}$ asilicalite-1 was used as the support to prepare $\mathrm{TiO}_{2}$-loaded $\mathrm{SiO}_{2}$ (asilicalite-1 $\left(\mathrm{TiO}_{2} \mathrm{QSiO}_{2}\right.$ @ silicalite-1). After five loading procedures, it could load $0.44 \% \mathrm{TiO}_{2}$ nanoparticles, which is higher than the $\mathrm{TiO}_{2}$ nanoparticle loading in traditional silicalite-1 $(0.13 \%)$. When the catalysts were used as a catalyst for the degradation of rhodamine B (RhB) aqueous solution under UV light, the photocatalytic efficiency of $\mathrm{TiO}_{2} \mathrm{aSiO}_{2}$ (asilicalite-1 (89.2\%) is higher than $\mathrm{TiO}_{2}$ (asilicalite-1 (only 34.6\%). The rate of degradation using $\mathrm{TiO}_{2} \mathrm{aSiO}_{2}$ @asilicalite-1 is 4.3 times faster than that using $\mathrm{TiO}_{2}$ (asilicalite-1. Furthermore, $\mathrm{SiO}_{2} \mathrm{CTiO}_{2}$ asilicalite-1 exhibits high stability of photocatalytic performance. After five repeated cycles, the photocatalytic efficiency of $\mathrm{TiO}_{2} \mathrm{CSiO}_{2}$ asilicalite-1 is $88.09 \%$, which reduces only by $1.1 \%$.
\end{abstract}

\section{Introduction}

Zeolites are microporous crystalline materials, which have high surface areas, excellent hydrothermal stability, controllable porosity and acid/basic/redox properties. Many zeolites have been discovered and used in industrial applications, ${ }^{1-5}$ such as NaX, ${ }^{6} \mathrm{MCM}-41,{ }^{7} 5 \mathrm{~A},{ }^{8}$ zeolite Y, ${ }^{9} \mathrm{ZSM}-5 .{ }^{10}$ They are composed of $\mathrm{SiO}_{4}$ and $\mathrm{AlO}_{4}$ tetrahedral structures and have been widely used as adsorbents, ${ }^{\mathbf{1 1 - 1 3}}$ ion exchangers and catalysts in the chemical industry. ${ }^{\mathbf{1 4 , 1 5}}$ Among these applications, zeolites were widely used as supporters in many fields. For example, Yang et al. employed SBA-15 as a support to load nanocrystalline titanium dioxide $\left(\mathrm{TiO}_{2}\right)$ in its pores, which showed much higher photodegradation ability for methylene blue than commercial pure P25 $\mathrm{TiO}_{2}$ nanoparticles. ${ }^{16}$ Panpranot et al. used MCM-41 as the support to develop MCM-41-supported CoRu catalysts for CO hydrogenation, in which $\mathrm{Co}$ and $\mathrm{Ru}$ were well loaded on the pores of MCM-41 and showed high activity. ${ }^{17}$

ZSM-5, a kind of crystalline microporous aluminosilicate with the MFI-type framework, has a strong and tunable acidity,

Fujian Key Laboratory of Advanced Materials, College of Materials, Xiamen University, Xiamen 361005, China. E-mail: xuetao@xmu.edu.cn excellent shape selectivity and good hydrothermal stability, leading to their wide use as sorbents, ${ }^{\mathbf{1 8 - 2 0}}$ catalysts, such as petrochemical processing for improving gasoline quality and producing important chemical materials. ${ }^{21-23}$ The properties of ZSM-5 zeolite are great influenced by the $\mathrm{Al}_{2} \mathrm{O}_{3} / \mathrm{SiO}_{2}$ ratio and the morphology. ${ }^{24}$ Recently, the high-silica ZSM-5 zeolite (silicalite-1) has received much attention because of its high shape selectivity for molecular sorption and diffusion, catalytic applications. ${ }^{25-27}$

Generally, silicalite-1 is synthesized as powders. It consists of pure $\mathrm{SiO}_{2}$ and has high surface areas. Accordingly, it is a potential to load some materials on silicalite-1, such as $\mathrm{TiO}_{2}$ nanoparticles. In our previous research, the surface of silicalite-1 is smooth and the cavity of silicalite- 1 is about $0.5-0.55 \mathrm{~nm} .{ }^{28}$ So it is difficult to load some materials on its surface firmly or in its pores due to its smooth surface and small cavity. What is more, when silicalite-1 is loaded with some materials in its pores, its surface area will decrease obviously. It can influence its catalytic activity significantly. In order to meet growing environmental challenges, it is important to explore new technologies to treat or synthesize silicalite-1 which can load a large amount of other materials and keep its large surface area. 
In this work, we demonstrate a sol-gel method for one-step synthesis of $\mathrm{SiO}_{2}$ @silicate-1 which has high crystallinity and rough surface. We also explored the formation of silicalite-1. Silicalite-1 grains are formed by transforming amorphous $\mathrm{SiO}_{2}$ into MFI-type structure. The surface of $\mathrm{SiO}_{2}$ @silicalite- 1 is coated with amorphous $\mathrm{SiO}_{2}$ nanoparticles and full with grooves. The amorphous $\mathrm{SiO}_{2}$ and grooves can provide more spaces for some materials to load on the surface of silicalite-1. Finally, $\mathrm{SiO}_{2} @$ silicalite-1 was used as support to load $\mathrm{TiO}_{2}$ nanoparticles. The catalytic activity of the catalyst was investigated by the photocatalytic degradation of RhB.

\section{Experimental}

\subsection{Synthesis of $\mathrm{SiO}_{2} @$ asilicalite-1}

All chemicals were purchased from Sinopharm Chemical Reagent Co.,Ltd (analytical grade) and used as received without further purification. The samples were synthesized by first adding $X \mathrm{~g}$ (where $X$ is $0.5,1,1.5$, respectively) tetrapropyl ammonium bromide (TPABr) and then $Y \mathrm{~g}$ (where $Y$ is $0.1,0.2$, 0.3 , respectively) sodium hydroxide to $30 \mathrm{ml}$ silica sol (30 $\mathrm{wt} \%$, $\mathrm{pH}=9.46$ ) under vigorous stirring for $2 \mathrm{~h}$ at room temperature. After that, the gel mixture was transferred to the Teflon-lined stainless-steel autoclave and heated at $180{ }^{\circ} \mathrm{C}$ in the baking oven for different time ( $3 \mathrm{~h}, 12 \mathrm{~h}, 24 \mathrm{~h})$. The schematic diagram of the synthetic procedure of core-shell $\mathrm{SiO}_{2}$ @silicalite- 1 is shown in Fig. 1. The obtained gelatinous monoliths were slightly poured out and dried at $60{ }^{\circ} \mathrm{C}$ for $48 \mathrm{~h}$. Finally, all samples were calcined at $550{ }^{\circ} \mathrm{C}$ for $6 \mathrm{~h}$ with the heating rate of $5{ }^{\circ} \mathrm{C} \min ^{-1}$ in the air atmosphere to remove the templates. And then, the core-shell $\mathrm{SiO}_{2} @$ silicalite- 1 was grinded into powders.

\subsection{Synthesis of $\mathrm{TiO}_{2} @ \mathrm{SiO}_{2} @$ @ilicalite-1}

$\mathrm{SiO}_{2}$ @silicalite-1 was used as support to load $\mathrm{TiO}_{2}$ nanocrystalline by the sol-gel method. The precursor solution of

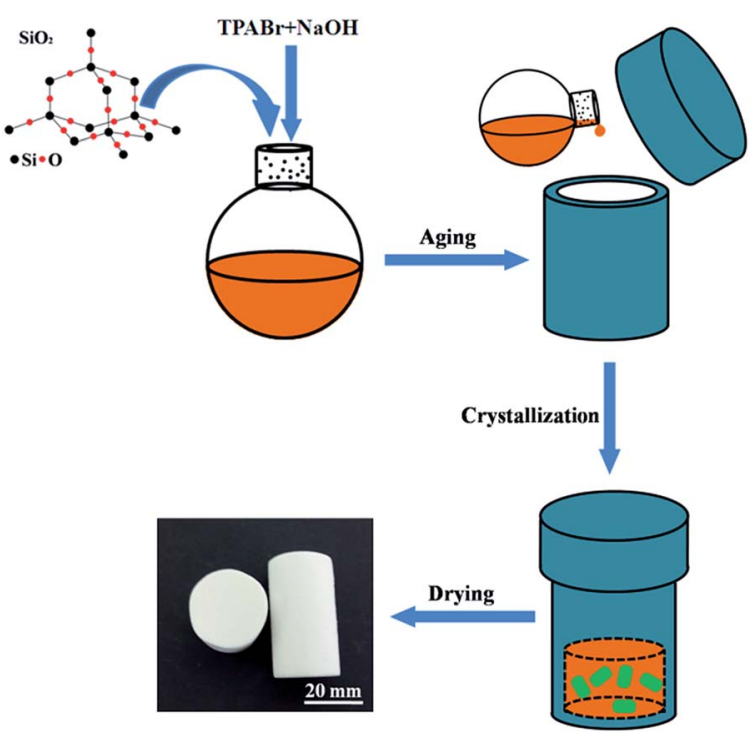

Fig. 1 Schematic diagram of the synthetic procedure and the synthesized $\mathrm{SiO}_{2}$ (asilicalite-1.
$\mathrm{TiO}_{2}$ was prepared as follows: $11.2 \mathrm{ml}$ tetrabutyl titanate (TBOT) and $2 \mathrm{ml}$ acetic acid were dissolved in $33.8 \mathrm{ml}$ absolute ethanol. The solution was stirred vigorously at room temperature for $20 \mathrm{~min}$, followed by the addition of a mixture containing $4.5 \mathrm{ml}$ distilled water, $10 \mathrm{ml}$ ethanol and $0.5 \mathrm{ml}$ nitric acid. Then, the solution was stirred continuously at room temperature to hydrolyze for 5 minutes to obtain a $\mathrm{TiO}_{2}$ sol. After that, $5 \mathrm{~g}$ $\mathrm{SiO}_{2}$ @silicalite-1 powders was immersed into the above solution. And the solution kept stirring for 20 minutes at room temperature. Then, the $\mathrm{TiO}_{2}$-loaded $\mathrm{SiO}_{2} @$ silicalite-1 $\left(\mathrm{TiO}_{2} @\right.$ $\mathrm{SiO}_{2}$ @silicalite-1) was filtrated and dried at drying oven and, subsequently, the process was repeated from immersion to drying for 5 times. Finally, $\mathrm{TiO}_{2} @ \mathrm{SiO}_{2} @$ asilicalite-1 was calcined at $550{ }^{\circ} \mathrm{C}$ in air for $2 \mathrm{~h}$, which resulted in the preparation of $\mathrm{TiO}_{2} @ \mathrm{SiO}_{2}$ @silicalite- 1 catalyst. In order to draw a comparison, the traditional silicalite- 1 was used as support to load $\mathrm{TiO}_{2}$ at the same process to prepare the $\mathrm{TiO}_{2}$ @ silicalite- 1 catalyst.

\subsection{Catalyst characterization}

The surface morphology of all ground samples was observed using scanning electron microscopy (SEM) on Hitachi SU-70 microscope at acceleration voltage of $5 \mathrm{kV}$. The X-ray powder diffraction patterns were recorded on a Bruker-AxsD8 diffractometer using $\mathrm{Cu}-\mathrm{K} \alpha$ radiation $(40 \mathrm{kV}$ and $40 \mathrm{~mA})$ in the angular range $(2 \theta)$ from 5 to $60^{\circ}$. Transmission electron microscopy (TEM) images were taken using a TEM (JEOL Model JEM-2100) operated at an accelerating voltage of $100 \mathrm{kV}$ using a $20 \mu \mathrm{m}$ aperture. UV-vis diffuse reflectance spectra was recorded on a UV101 PC scanning spectrophotometer. The nitrogen adsorptiondesorption isotherm were recorded using TriStar 3020 (Micromeritics, USA) analyzer. The specific surface areas were calculated using the multiple-point Brunauer-Emmett-Teller (BET) method by the Barrett-Joyner-Halenda (BJH) model. The micropore size distribution was measured using the HorvathKawazoe (HK) analysis method.

\subsection{Catalytic evaluation}

In order to evaluate the catalytic activity of the catalyst, all samples were used to degrade the rhodamine B (RhB) solution in an inclosed box with side the volume of $25 \times 25 \times 25 \mathrm{~cm}^{3}$. A Philips lamp irradiating UV light with the power of $40 \mathrm{~W}$ was fixed on the top of the box. The distance between the UV light and the reactor is $26 \mathrm{~cm}$. And a magnetic stirrer was located at the bottom of the box. Before UV light irradiation, the solution was stirred continuously in the dark for $30 \mathrm{~min}$ to ensure the adsorption-desorption equilibrium between $\mathrm{RhB}$ and the catalyst. Afterwards, the UV light was turned on and the solution was irradiated for $90 \mathrm{~min}$. In order to determine the residual dye concentration in solution during this time, a few milliliters of the solution was withdrawn from the reactor and centrifuged to remove the photocatalyst before measuring. The fractional degradation efficiency $\left(D_{\mathrm{R}}\right)$ of $\mathrm{RhB}$ was calculated by the following equation:

$$
D_{\mathrm{R}}(\%)=\frac{\left(C_{0}-C_{t}\right)}{C_{0}} \times 100
$$


where $C_{0}$ is the initial concentration of $\mathrm{RhB}$ and $C_{t}$ is the concentration at definite interval of time, respectively.

\section{Results and discussion}

\subsection{Preparation of $\mathrm{SiO}_{2} @$ silicalite-1 and its characterization}

3.1.1. Effects of alkalinity. $\mathrm{SiO}_{2}$ @ silicalite- 1 was synthesized by sol-gel method. The effect of alkalinity on the morphology and crystallinity of $\mathrm{SiO}_{2}$ @silicalite- 1 was investigated. The sol composition was composed of $30 \mathrm{ml}$ silica sol, $1 \mathrm{~g}$ $\mathrm{TPABr}, X \mathrm{~g} \mathrm{NaOH}$ (where $X$ was $0.1,0.2$, and 0.3 , respectively) and crystallized at $180^{\circ} \mathrm{C}$ for $24 \mathrm{~h}$. Fig. 2 shows the SEM images and XRD patterns of products prepared with different $\mathrm{NaOH} /$ $\mathrm{SiO}_{2}$ mass ratios. From the XRD patterns of Fig. 2, it can be seen that three samples show distinct peaks at $7.98^{\circ}, 8.82^{\circ}, 13.24^{\circ}$, $13.94^{\circ}, 14.80^{\circ}, 15.53^{\circ}, 15.89^{\circ}, 17.79^{\circ}, 20.37^{\circ}, 23.18^{\circ}, 24.02^{\circ}$ and $24.46^{\circ}$, which are ascribable to (101), (020), (300), (012), (301), (202), (040), (031), (501), (151) and (303) reflections of silicalite1. It indicates that silicalite-1 is formed in three samples. ${ }^{29,30}$ Fig. $2 \mathrm{a}-\mathrm{c}$ are SEM images of three samples. It can be seen that all silicalite- 1 grains exhibit the twinned structure. And the particle size of silicalite- 1 has a close relative with the sodium hydroxide content. When the sample is synthesized with the $\mathrm{NaOH} / \mathrm{SiO}_{2}$ mass ratio of $0.1: 9$, it is composed of silica and silicalite- 1 crystals. The particle size of silicalite- 1 is about 40 $\mu \mathrm{m}$ (Fig. 2a). With the increase of the $\mathrm{NaOH} / \mathrm{SiO}_{2}$ mass ratio (from $0.1: 9$ to $0.3: 9$ ), the particle size of silicalite- 1 particles decreases (from $40 \mu \mathrm{m}$ to $25 \mu \mathrm{m}$ ). It indicates that more nuclei are formed at the higher sodium hydroxide content and relative smaller crystals are produced. It is in agreement with Watanabe's group experiments. ${ }^{31}$ Fegan's group has also reported that crystals formed at high alkalinity are smaller. ${ }^{32}$ Except silicalite-1 particles, there is also existing amorphous silica around silicalite-1 particles. Fig. 2 also shows the XRD patterns of the three samples. The intensity of diffraction peaks of silicalite-1 increases when the $\mathrm{NaOH} / \mathrm{SiO}_{2}$ previous work, we successfully synthesized the silicalite- 1 with high crystallinity. ${ }^{28}$ Using the synthesized silicalite-1 as comparison, the
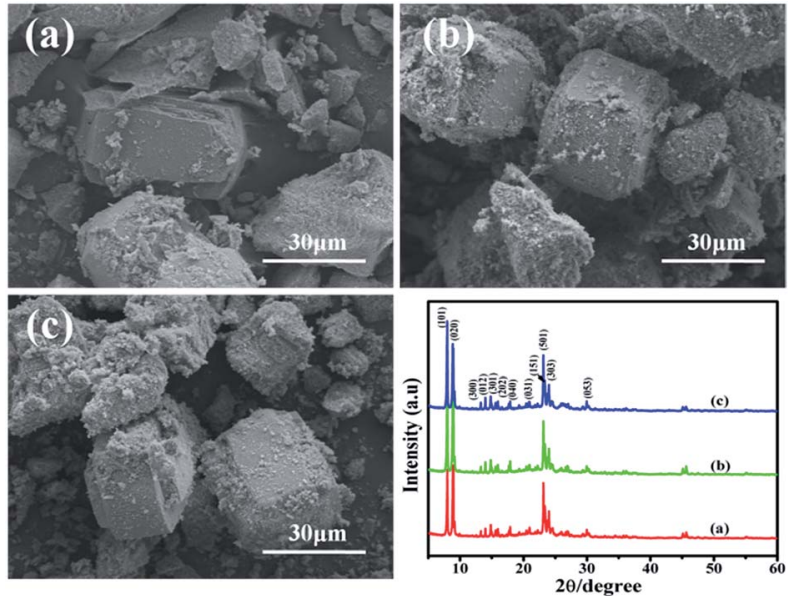

Fig. 2 SEM images of products prepared with $\mathrm{NaOH} / \mathrm{SiO}_{2}$ mass ratios of (a) $0.1: 9$, (b) $0.2: 9$, (c) $0.3: 9$ and XRD patterns. crystallinity degree of $\mathrm{SiO}_{2}$ @silicalite- 1 is $68.95 \%, 82.71 \%$, $77.19 \%$, respectively. It indicates that when the $\mathrm{NaOH} / \mathrm{SiO}_{2}$ mass ratio is $0.2: 9$, it is beneficial to synthesize the MFI-type structure. The result is in line with the observations reported in the literature. ${ }^{33}$

3.1.2. Effects of tetrapropyl ammonium bromide (TPABr). In this experiment, we investigated the effect of the TPABr content on synthesizing the $\mathrm{SiO}_{2}$ @silicalite- 1 . The products were synthesized at $180{ }^{\circ} \mathrm{C}$ for $24 \mathrm{~h}$ with a sol composition of $30 \mathrm{ml}$ silica sol, $0.2 \mathrm{~g} \mathrm{NaOH}, X \mathrm{~g}$ TPABr $(X$ is $0.5,1.0$, and 1.5, respectively). Fig. 3 shows the SEM images and XRD patterns with different $\mathrm{TPABr}$ content. It can be noted that when the product is synthesized with $0.5 \mathrm{~g} \mathrm{TPABr}$, there are a lot of amorphous $\mathrm{SiO}_{2}$ particles around silicalite- 1 particles. The crystallinity degree is only $28.75 \%$. Except the characteristic peaks of silicalite-1, the XRD patterns of the sample with $0.5 \mathrm{~g}$ TPABr also shows a wide range diffraction from 20 to $25^{\circ}$, which is corresponding to amorphous $\mathrm{SiO}_{2}$. The average particles size of silicalite- 1 as estimated by SEM is about $50 \mu \mathrm{m}$. When the TPABr content is $1.0 \mathrm{~g}$, the average particles size of silicalite- 1 is about $40 \mu \mathrm{m}$ and the crystallinity degree is $82.71 \%$. When the TPABr content increases further $(1.5 \mathrm{~g})$, the average particles size of silicalite-1 decreases continuously $(20 \mu \mathrm{m})$. And the crystallinity degree of silicalite- 1 is increased to $88.11 \%$. TPABr content can promote the formation of silicalite-1 nuclei.

3.1.3. Effects of crystallization time. By controlling the amount of sodium hydroxide and TPABr in the synthesis gel, we obtained the suitable alkalinity and TPABr content on synthesizing the $\mathrm{SiO}_{2} @$ @ilicalite-1. In this experiment, the composition of the precursor solution was $30 \mathrm{ml}$ silica sol, $0.2 \mathrm{~g} \mathrm{NaOH}$, $1.5 \mathrm{~g}$ TPABr. It was aging for $2 \mathrm{~h}$ at room temperature and crystallized at $180{ }^{\circ} \mathrm{C}$ for different time. The effect of crystallization time was examined. Fig. 4 shows the SEM images and XRD patterns of products crystallized with different crystallization time that fell within the $3-24 \mathrm{~h}$ range.

Fig. $4 \mathrm{a}$ is the SME image of the product which is crystallized for $3 \mathrm{~h}$. It can be seen that silicalite-1 particles are not formed. The XRD patterns just shows weak characteristic peaks of
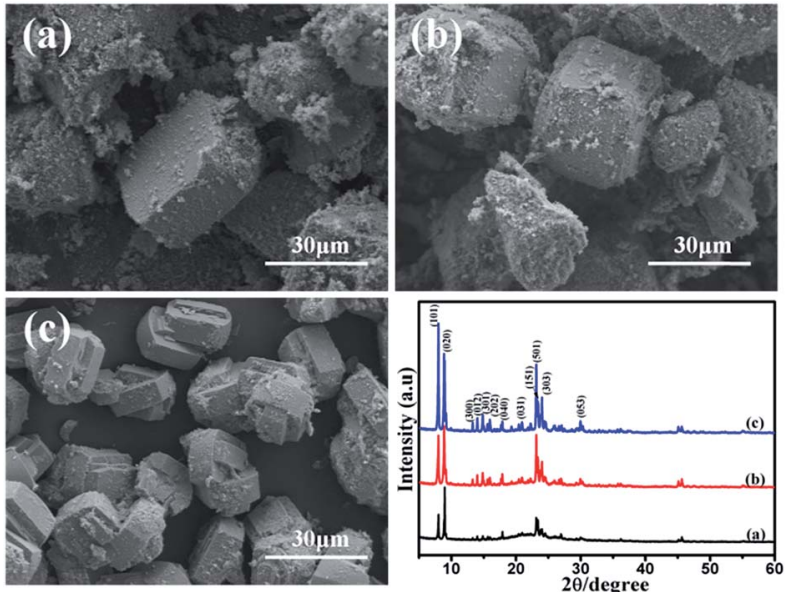

Fig. 3 SEM images of products prepared with different amount of TPABr (a) $0.5 \mathrm{~g}$, (b) $1.0 \mathrm{~g}$, (c) $1.5 \mathrm{~g}$ and XRD patterns. 

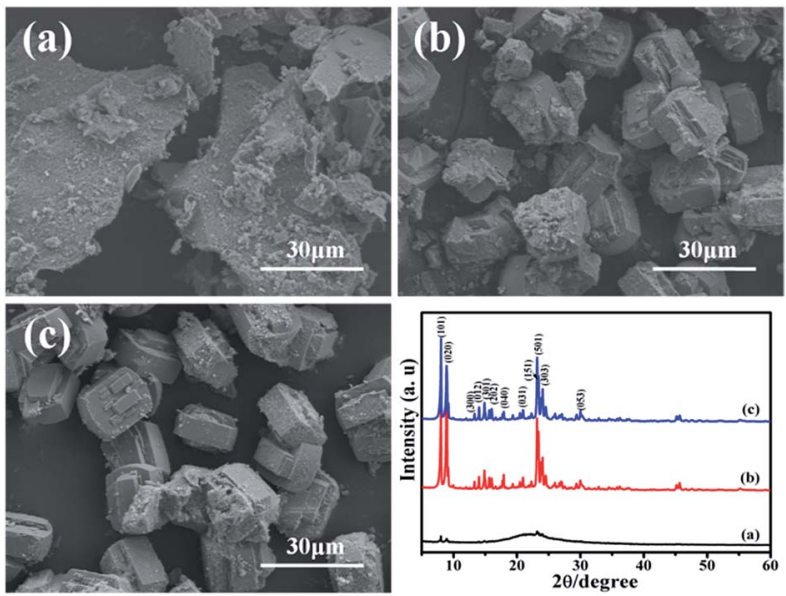

Fig. 4 SEM images of products prepared with a crystallization time of (a) $3 \mathrm{~h}$, (b) $12 \mathrm{~h}$, (c) $24 \mathrm{~h}$ and XRD patterns

silicalite- 1 and exhibits a wide range diffraction from 20 to $25^{\circ}$, which is corresponding to amorphous $\mathrm{SiO}_{2}$. It can be inferred that $\mathrm{SiO}_{2}$ colloidal particles just aggregate and form gelation with the three-dimensional net structure after $3 \mathrm{~h}$ of hydrothermal treatment. ${ }^{34}$ The solvent and solute are immobilized in the three-dimensional net structure and loses its mobility. After being dried, water molecules are evaporated and $\mathrm{SiO}_{2}$ colloidal particles are left and bond together. When the product is synthesized by crystallizing for $12 \mathrm{~h}$, it shows the obvious characteristic peaks of silicalite-1. And silicalite-1 particles exhibit the twinned-lozenge shape and the average crystal size of the harvested particles is about $20 \mu \mathrm{m}$ (Fig. 4b). The crystallinity degree is about $117.76 \%$. Further extension of the crystallization time (after $24 \mathrm{~h}$ ), the particle size shape and crystal size of silicalite- 1 are almost the same with the sample crystallizing for $12 \mathrm{~h}$ (Fig. 4c). But the crystallinity degree decreases to $88.11 \%$. It indicates that $12 \mathrm{~h}$ is the suitable time to form silicalite-1 zeolite.

\subsection{Preparation of $\mathrm{TiO}_{2} @ \mathrm{SiO}_{2} @$ asilicalite-1 and its characterization}

In order to draw a comparison, the traditional silicalite- 1 was synthesized according to our previous report. ${ }^{28}$ In a typical process, $40 \mathrm{ml}$ of silica sol (30 wt\%, pH =9.46) and $60 \mathrm{ml}$ of distilled water were mixed together. Then $1.5 \mathrm{~g}$ of sodium hydroxide and $3 \mathrm{~g}$ of tetrapropylammonium bromide were added into above mixture. After the mixture was stirred at room temperature for $6 \mathrm{~h}$, the obtained gel precursor was transformed into the Teflon-lined stainless-steel autoclave and heated at $180{ }^{\circ} \mathrm{C}$ for $24 \mathrm{~h}$ to obtain the silicalite-1. Fig. 5 illustrates the high magnification SEM images of silicalite-1 and $\mathrm{SiO}_{2} @$ silicalite-1. It can be seen that the surface of the traditional silicalite-1 is smooth (Fig. 5a). Fig. $5 \mathrm{~b}$ is the high magnification SEM images of $\mathrm{SiO}_{2} @$ silicalite-1. It can be seen that the surface of $\mathrm{SiO}_{2}$ @silicalite- 1 coats with nanoparticles. The size of the nanoparticles is about $50 \mathrm{~nm}$. Except these nanoparticles, there are also existing lots of grooves.

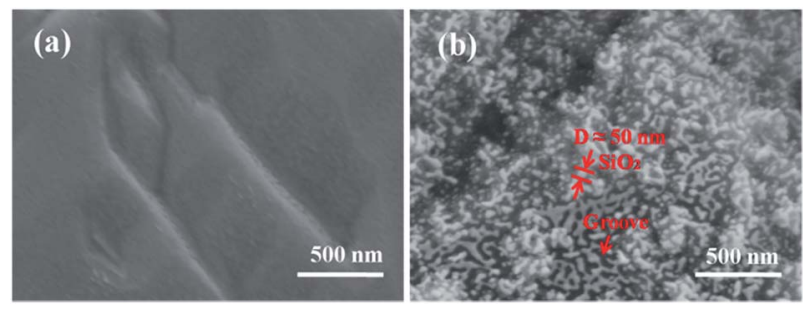

Fig. 5 High magnification SEM images of (a) silicalite-1 and (b) $\mathrm{SiO}_{2}$ asilicalite-1.

In order to investigate the physicochemical properties of the $\mathrm{SiO}_{2}$ @silicalite-1 (30 ml silica sol, $0.3 \mathrm{~g} \mathrm{NaOH}, 1.5 \mathrm{~g} \mathrm{TPABr}$, crystallized for $12 \mathrm{~h}$ ), BET techniques was employed. As references, silicalite-1 $(15 \mu \mathrm{m})$ and $\mathrm{SiO}_{2}$ @silicalite- 1 were characterized. The nitrogen sorption isotherms and pore size distributions are shown in Fig. 6. It can be seen that the nitrogen sorption isotherms of silicalite- 1 and $\mathrm{SiO}_{2}$ @silicalite-1 are both type I, which shows a steep increase at low relative pressure $\left(P / P_{0}<0.1\right)$ region corresponding to the presence of micropores in the samples. ${ }^{35}$ Silicalite- 1 and $\mathrm{SiO}_{2}$ @silicalite- 1 almost keep the same micropore size distribution and have a very narrow micropore size distribution with a mean pore diameter of $0.5-0.55 \mathrm{~nm}$, which is comparable to the pore diameter of the crystallographic five membered ring of silicalite1.

The textural properties of the synthesized silicalite- 1 and $\mathrm{SiO}_{2}$ @silicalite- 1 are shown in Table 1. The particle size of silicalite-1 and $\mathrm{SiO}_{2} @$ allicalite- 1 are 15 and $20 \mu \mathrm{m}$, respectively. The BET surface area and external surface area of silicalite- 1 are $334 \mathrm{~m}^{2} \mathrm{~g}^{-1}$ and $195 \mathrm{~m}^{2} \mathrm{~g}^{-1}$, respectively. When the sample is formed into $\mathrm{SiO}_{2}$ @silicalite-1, it keeps the high BET surface area $\left(279 \mathrm{~m}^{2} \mathrm{~g}^{-1}\right)$.
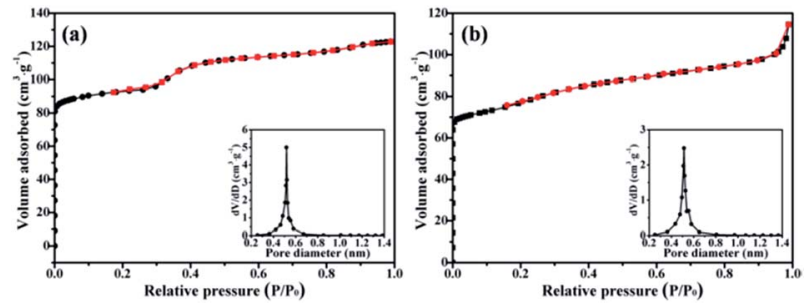

Fig. 6 Nitrogen sorption isotherms and pore size distribution of (a) silicalite-1 and (b) $\mathrm{SiO}_{2}$ (asilicalite-1.

Table 1 Textural characteristic of silicalite-1 and $\mathrm{SiO}_{2}$ @asilicalite-1

\begin{tabular}{lllll}
\hline Catalyst & $\begin{array}{l}\text { Particle } \\
\operatorname{size}^{a}(\mu \mathrm{m})\end{array}$ & $\begin{array}{l}S_{\mathrm{BET}}{ }^{b} \\
\left(\mathrm{~m}^{2} \mathrm{~g}^{-1}\right)\end{array}$ & $\begin{array}{l}S_{\mathrm{EXT}}{ }^{c} \\
\left(\mathrm{~m}^{2} \mathrm{~g}^{-1}\right)\end{array}$ & $\begin{array}{l}V^{d} \\
\left(\mathrm{ml} \mathrm{g}^{-1}\right)\end{array}$ \\
\hline Silicalite-1 & 15 & 334 & 195 & 0.190 \\
$\mathrm{SiO}_{2} @$ silicalite-1 & 20 & 279 & 161 & 0.177
\end{tabular}

${ }^{a}$ Particle size: estimated based on SEM results. ${ }^{b} S_{\mathrm{BET}}$ : BET surface area. ${ }^{c} S_{\mathrm{EXT}}$ : external surface area. ${ }^{d} V$ : micropore volume. 

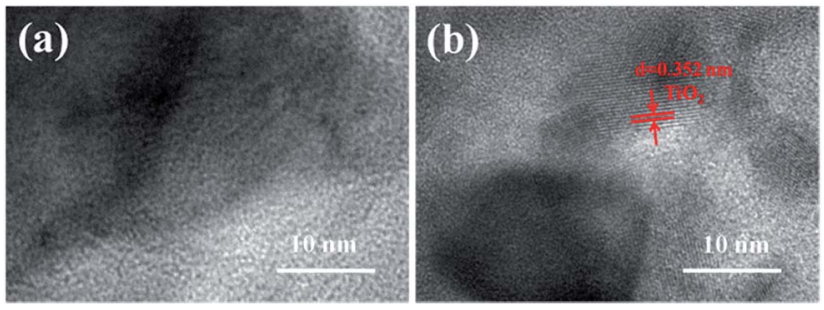

Fig. 7 TEM images of (a) $\mathrm{SiO}_{2}\left(\right.$ asilicalite-1 and (b) $\mathrm{TiO}_{2} \mathrm{aSiO}_{2} \mathrm{a}-$ silicalite-1

Fig. 7 shows the TEM images of $\mathrm{SiO}_{2}$ @silicalite- 1 and $\mathrm{TiO}_{2} @ \mathrm{SiO}_{2} @$ silicalite-1. The $\mathrm{SiO}_{2}$ @silicalite-1 was synthesized with the sol composition of $30 \mathrm{ml}$ silica sol, $0.2 \mathrm{~g} \mathrm{NaOH}$, and $1.5 \mathrm{~g}$ TPABr. The high magnification SEM image of $\mathrm{SiO}_{2} @-$ silicalite-1 (Fig. 5a) shows that the surface of $\mathrm{SiO}_{2} @$ @ilicalite-1 is coated with nanoparticles. From Fig. 7a, it can be seen that these nanoparticles are amorphous and aggregate together. It can be inferred that silicalite-1 grains are formed in the threedimensional net structure of silica and grow in situ by transforming amorphous $\mathrm{SiO}_{2}$ into MFI-type structure. Fig. $7 \mathrm{~b}$ is the high magnification TEM image of $\mathrm{TiO}_{2} @ \mathrm{SiO}_{2} @$ asilicalite-1. It can be seen that there are existing diffractions with lattice constant of 0.352. It indicates that $\mathrm{TiO}_{2}$ is well loaded in the pores of amorphous $\mathrm{SiO}_{2}$.

In the preparation of $\mathrm{TiO}_{2}$-loaded $\mathrm{SiO}_{2}$ @silicalite- $1\left(\mathrm{TiO}_{2} @\right.$ $\mathrm{SiO}_{2} @$ @ilicalite-1), we used the $\mathrm{SiO}_{2} @$ @ilicalite-1 as support, which was synthesized with $30 \mathrm{ml}$ silica sol, $0.2 \mathrm{~g} \mathrm{NaOH}, 1.5 \mathrm{~g}$ TPABr and crystallized for $12 \mathrm{~h}$ at $180{ }^{\circ} \mathrm{C}$. The synthetic procedure is given as above. Fig. 8 shows that diffuse reflectance UVvis spectra of $\mathrm{SiO}_{2} @$ silicalite-1, $\mathrm{TiO}_{2}$ @silicalite-1, and $\mathrm{TiO}_{2} @$ @$\mathrm{SiO}_{2} @$ @ilicalite-1. It can be seen that $\mathrm{SiO}_{2}$ @silicalite-1 just shows a gentle absorption band at about $250-280 \mathrm{~nm}$. When silicalite-1 and $\mathrm{SiO}_{2} @$ asilicalite-1 are loaded with $\mathrm{TiO}_{2}$ nanoparticles, they all exhibit a highly intense band at about $388 \mathrm{~nm}$. According to the Kubelka-Munk radiative transfer model, the band gap $\left(E_{\mathrm{g}}\right)$ of $\mathrm{TiO}_{2} @$ @silicalite-1 and $\mathrm{TiO}_{2} @ \mathrm{SiO}_{2} @$ silicalite-1

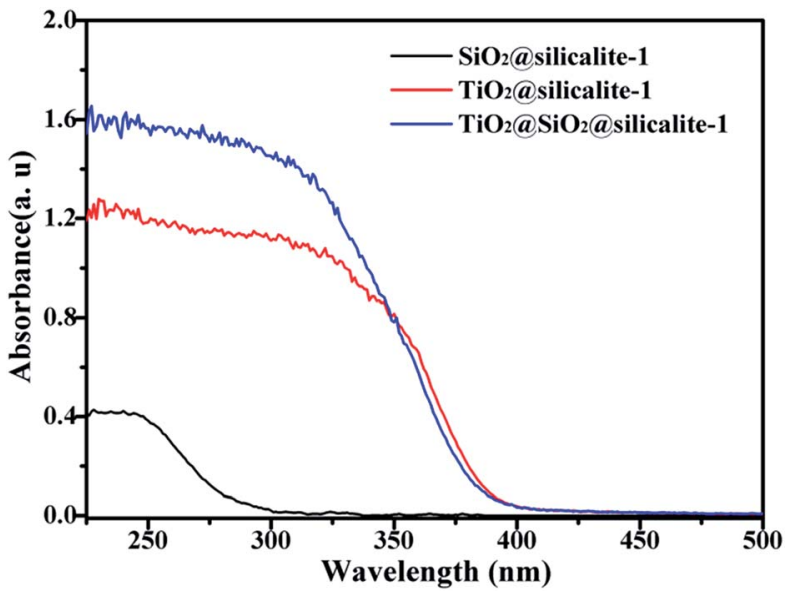

Fig. 8 UV-vis spectra of silicalite-1, $\mathrm{TiO}_{2}$ @ asilicalite-1 and $\mathrm{TiO}_{2} @-$ $\mathrm{SiO}_{2}$ asilicalite-1. are about $3.2 \mathrm{eV}^{36}$ It indicates that $\mathrm{TiO}_{2}$ nanoparticles are successfully loaded silicalite-1 and $\mathrm{SiO}_{2} @$ silicalite- 1 . However, from Fig. 8, it can be found that the absorption peak of $\mathrm{TiO}_{2} @ \mathrm{SiO}_{2} @$ @ilicalite-1 corresponding to $\mathrm{TiO}_{2}$ is higher than $\mathrm{TiO}_{2} @$ @ilicalite-1. It can be inferred that content of $\mathrm{TiO}_{2}$ in $\mathrm{TiO}_{2} @ \mathrm{SiO}_{2} @$ @silicalite-1 may be higher than in $\mathrm{TiO}_{2} @$ silicalite-1.

The catalytic performance of all samples was examined by degradation of RhB. Fig. 9a shows the results of RhB removal by the catalysts. In order to ensure the adsorption-desorption equilibrium between $\mathrm{RhB}$ and the catalyst, all samples were mixed with RhB solution and stirred in the dark. After 30 min of continuously stirring in the dark, $5.24 \%$ of $\mathrm{RhB}$ is absorbed by $\mathrm{SiO}_{2}$ @silicalite-1. When $\mathrm{SiO}_{2}$ @silicalite-1 is loaded with $\mathrm{TiO}_{2}$, it shows $4.75 \%$ absorption. The adsorptive property of the catalyst is reduced, which may be contributed to the loading of $\mathrm{TiO}_{2}$ in the pores of $\mathrm{SiO}_{2} @$ @ilicalite-1. The absorption of $\mathrm{TiO}_{2}$ @silicalite- 1 is $5.22 \%$, which is higher than $\mathrm{TiO}_{2} @ \mathrm{SiO}_{2} @$ silicalite1. It may be the reason that the surface area of $\mathrm{TiO}_{2}$ @silicalite-1 is higher than the surface of $\mathrm{TiO}_{2} @ \mathrm{SiO}_{2} @$ silicalite-1. Then, all experiments are exposed under the UV light for $120 \mathrm{~min}$. From Fig. 9a, we can see that $4.68 \%$ of $\mathrm{RhB}$ is degraded by itself under the UV light. The existing of $\mathrm{SiO}_{2} @$ silicalite-1 powders cannot accelerate the degradation of $\mathrm{RhB}$. When $\mathrm{SiO}_{2}$ @silicate-1 is loaded with $\mathrm{TiO}_{2}$ nanoparticles, it can degrade $89.19 \%$ of $\mathrm{RhB}$. It shows high photocatalytic activity. And the traditional silicalite-1 was used as support to load $\mathrm{TiO}_{2}$ at the same process to prepare the $\mathrm{TiO}_{2}$ @silicalite- 1 catalyst. Only $34.58 \%$ of $\mathrm{RhB}$ is degraded by $\mathrm{TiO}_{2} @$ @silicalite- 1 catalyst. The catalytic activity of $\mathrm{TiO}_{2} @ \mathrm{SiO}_{2} @$ silicalite-1 is higher than $\mathrm{TiO}_{2} @$ @ilicalite-1. It may be the reason that $\mathrm{SiO}_{2}$ @silicalite-1 can load more $\mathrm{TiO}_{2}$ than the traditional silicalite-1. The kinetics of all samples for degradation of RhB under UV light irradiation is illustrated in Fig. 9b. The photocatalysis degradation kinetic reaction can be described by pseudo-first-rate order kinetics, $\operatorname{In}\left(C_{0} / C\right)=k t$, where $k$ is a pseudo-first-rate kinetic constant and $t$ is the irradiation time. The calculated $k$ value of $\mathrm{TiO}_{2} @$ silicalite- 1 is $0.00384 \mathrm{~min}^{-1}$. For $\mathrm{SiO}_{2} @ \mathrm{TiO}_{2} @$ asilicalite-1, the calculated $k$ value is $0.0165 \mathrm{~min}^{-1}$, which is 4.3 times the $k$ value of $\mathrm{TiO}_{2} @$ silicalite-1. The photocatalysis activity of the composite is improved greatly. Accordingly, the change of the photocatalytic activity of $\mathrm{TiO}_{2} @ \mathrm{SiO}_{2} @$ silicalite- 1 catalyst is probably due to the increase of $\mathrm{TiO}_{2}$ loading in the catalyst. More $\mathrm{TiO}_{2}$ nanoparticles can be loaded in the pores of amorphous $\mathrm{SiO}_{2}$ and the grooves of silicalite-1.
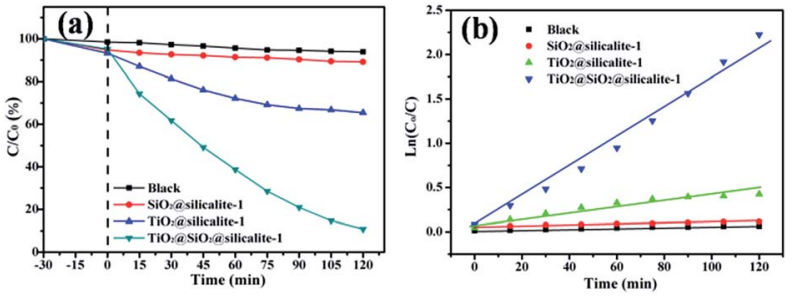

Fig. 9 Photocatalytic degradation (a) and kinetics (b) of blank, silicalite-1, $\mathrm{TiO}_{2}$ (asilicalite-1 and $\mathrm{TiO}_{2} \mathrm{CSiO}_{2}$ asilicalite-1 for degradation of $\mathrm{RhB}$ in the dark and under UV light irradiation with a catalyst content of $1 \mathrm{~g} \mathrm{l}^{-1}, \mathrm{C}_{0}=5 \mathrm{mg} \mathrm{l}^{-1}$. 


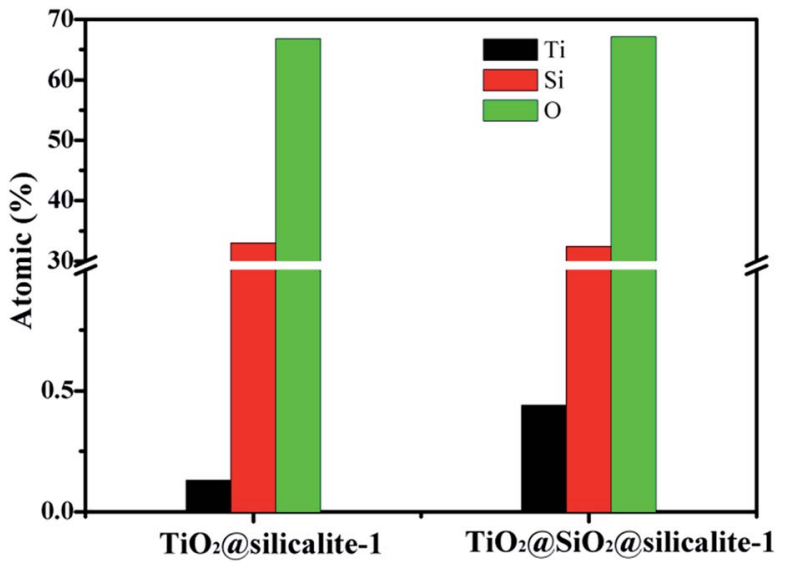

Fig. 10 The content of $\mathrm{Ti}, \mathrm{Si}, \mathrm{O}$ element in $\mathrm{TiO}_{2}$ (asilicalite-1 and $\mathrm{TiO}_{2} @ \mathrm{aSiO}_{2}$ (asilicalite-1.

The energy dispersive spectrometer of $\mathrm{TiO}_{2}$ @silicalite- 1 and $\mathrm{TiO}_{2} @ \mathrm{SiO}_{2} @$ silicalite-1 was measured by a Hitachi SU70 microscope and the element proportion was shown in Fig. 10. It can be seen that the atomic ratio of $\mathrm{O} / \mathrm{Si}$ of $\mathrm{TiO}_{2} @$ silicalite- 1 and $\mathrm{TiO}_{2} @ \mathrm{SiO}_{2} @$ silicalite-1 is about 2. After five times of loading, the $\mathrm{Ti}$ element in $\mathrm{TiO}_{2}$ @silicalite- 1 is just $0.13 \%$. However, the Ti element in $\mathrm{TiO}_{2} @ \mathrm{SiO}_{2} @$ asilicalite- 1 is $0.44 \%$, which is almost 3.48 times the $\mathrm{Ti}$ content of $\mathrm{TiO}_{2} @$ silicalite- 1 .

More $\mathrm{TiO}_{2}$ nanoparticles can be loaded in the pores of amorphous $\mathrm{SiO}_{2}$ and grooves on silicalite-1 surface.

In order to investigate the stability of photocatalytic performance under UV light, $\mathrm{TiO}_{2} @ \mathrm{SiO}_{2} @$ @ilicalite-1 was used as catalyst to degrade $\mathrm{RhB}$ in five repeated cycles. The results are shown in Fig. 11. From Fig. 11, it can be seen that the photocatalytic performance of $\mathrm{SiO}_{2} @ \mathrm{TiO}_{2} @$ silicalite-1 exhibits effective photostability under the UV light. After five repeated cycles, the photocatalytic efficiency of $\mathrm{TiO}_{2} @ \mathrm{SiO}_{2} @$ asilicalite- 1 is $88.09 \%$, which reduces only by $1.1 \%$. It may be the reason that $\mathrm{TiO}_{2}$ nanoparticles load in the pores of amorphous of $\mathrm{SiO}_{2}$ and tightly adhere on the surface of silicalite- 1 .

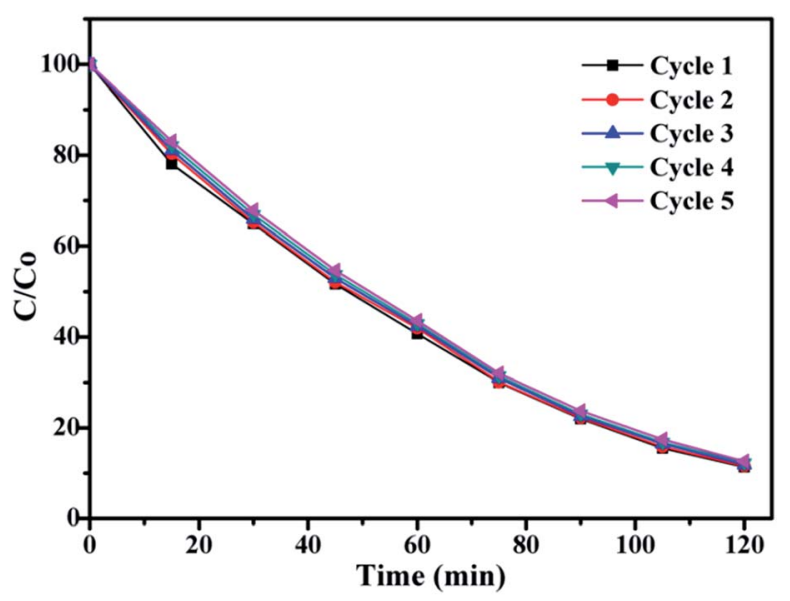

Fig. 11 Five photocatalytic degradation cycles of $\mathrm{RhB}$ using $\mathrm{TiO}_{2} \mathrm{a}$ $\mathrm{SiO}_{2}$ asilicalite-1 under UV light.

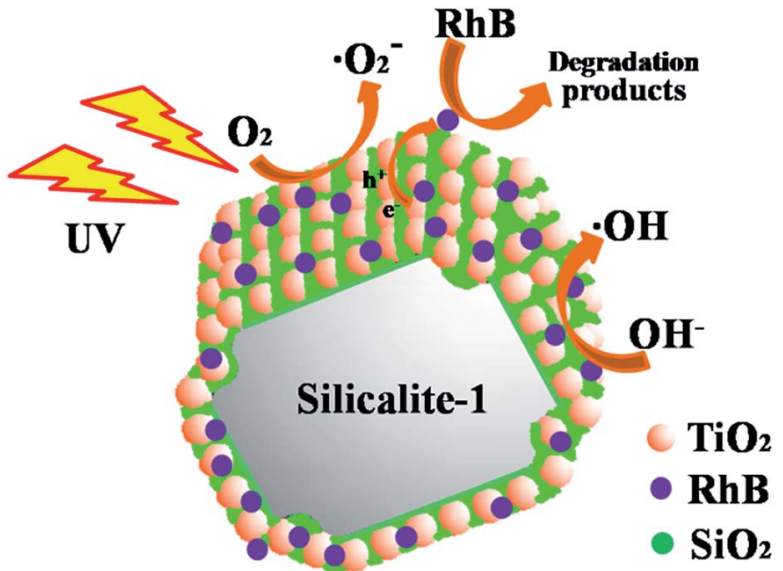

Fig. 12 The schematic diagram for the adsorption and photocatalytic degradation of RhB molecules on catalyst.

Fig. 12 shows the schematic diagram for the adsorption and photocatalytic degradation of RhB molecules on catalyst. As we know silicalite- 1 zeolite has high adsorptive property. It can keep a high RhB concentration on its surface for its adsorption. After a period of contact, there is an adsorption-desorption equilibrium between the catalyst and the solution. When $\mathrm{TiO}_{2}$ particles are loaded on $\mathrm{SiO}_{2}$ @silicalite- 1 and irradiated by UV light, it can generate the hydroxyl radicals and valence band holes to oxidize RhB molecules into inorganic compounds. The adsorption of the zeolites and photocatalysis of the deposited $\mathrm{TiO}_{2}$ have been combined, resulting in synergistic effects in improving the photocatalytic efficiency of $\mathrm{TiO}_{2}$. When $\mathrm{SiO}_{2}$ @silicalite-1 monolith is loaded with $\mathrm{TiO}_{2}$ particles, it can degrade RhB molecular effectively. From Fig. 9a, it can be seen that after 120 min of UV light irradiation, $89.19 \%$ of RhB is degraded. The catalyst shows high photocatalytic activity.

\section{Conclusions}

A series of $\mathrm{SiO}_{2}$ @silicalite-1 with different silicalite-1 particle size and crystallinity degree were synthesized according to the hydrothermal method using silica sol as Si source, TPABr as template. By adding an appropriate amount of tetrapropyl ammonium bromide and sodium hydroxide in the silica sol and controlling the crystallization time, the crystallinity degree of silicalite- 1 monolith can be $117.76 \%$ comparing to the synthesized silicalite- $1 . \mathrm{SiO}_{2}$ @silicalite-1 containing $\mathrm{TiO}_{2}\left(\mathrm{TiO}_{2} @ \mathrm{SiO}_{2}\right.$ @silicalite-1) was also prepared by a sol-gel method. $\mathrm{TiO}_{2}$ was well loaded on the pores of amorphous $\mathrm{SiO}_{2}$ and the grooves of silicalite- 1 surface. And it shows high catalytic performance for degradation of $\mathrm{RhB}$ and keeps high stability of photocatalytic performance. $\mathrm{SiO}_{2} @$ silicalite1 is potential to be used as support to load same materials using in different catalysis.

\section{Acknowledgements}

The authors grateful acknowledge financial supported by the Scientific Technological Innovation Platform of Fujian Province (2006L2003). 


\section{References}

1 L. A. Truter, V. Ordomsky, J. C. Schouten and T. A. Nijhuis, Appl. Catal., A, 2016, 515, 72-82.

2 Y. Jiao, X. Yang, C. Jiang, C. Tian, Z. Yang and J. Zhang, J. Catal., 2015, 332, 70-76.

3 J. Čejka, G. Centi, J. Perez-Pariente and W. J. Roth, Catal. Today, 2012, 179, 2-15.

4 S. L. Hailu, B. U. Nair, M. Redi-Abshiro, R. Aravindhan, I. Diaz and M. Tessema, J. Porous Mater., 2015, 22, 13631373.

5 H. Liu, S. Peng, L. Shu, T. Chen, T. Bao and R. L. Frost, Chemosphere, 2013, 91, 1539-1546.

6 M. A. S. D. Barros, E. A. Silva, P. A. Arroyo, C. R. G. Tavares, R. M. Schneider, M. Suszek and E. F. Sousa-Aguiar, Chem. Eng. Sci., 2004, 59, 5959-5966.

7 Q. Guan, F. Wan, F. Han, Z. Liu and W. Li, Catal. Today, 2016, 259, 467-473.

8 Y. H. Zhuonan Song, L. Wang, S. Li and M. Yu, Chem. Commun., 2015, 51, 373-375.

9 J. García-Martínez, M. Johnson, J. Valla, K. Li and J. Y. Ying, Catal. Sci. Technol., 2012, 2, 987.

10 Y.-T. Cheng, J. Jae, J. Shi, W. Fan and G. W. Huber, Angew. Chem., Int. Ed., 2012, 51, 1387-1390.

11 J. A. Thompson, N. A. Brunelli, R. P. Lively, J. R. Johnson, C. W. Jones and S. Nair, J. Phys. Chem. C, 2013, 117, 81988207.

12 A. Nanoti, S. Dasgupta, Aarti, N. Biswas, A. N. Goswami, M. O. Garg, S. Divekar and C. Pendem, Ind. Eng. Chem. Res., 2012, 51, 13765-13772.

13 L. R. Rad, A. Momeni, B. F. Ghazani, M. Irani, M. Mahmoudi and B. Noghreh, Chem. Eng. J., 2014, 256, 119-127.

14 Z. Zhang, M. Sadakane, T. Murayama, N. Sakaguchi and W. Ueda, Inorg. Chem., 2014, 53, 7309-7318.

15 A. M. Abdel-Mageed, S. Eckle, H. G. Anfang and R. J. Behm, J. Catal., 2013, 298, 148-160.

16 J. Yang, J. Zhang, L. Zhu, S. Chen, Y. Zhang, Y. Tang, Y. Zhu and Y. Li, J. Hazard. Mater., 2006, 137, 952-958.
17 J. Panpranot, J. G. Goodwin Jr and A. Sayari, J. Catal., 2002, 211, 530-539.

18 D. Liu, W. Zhou and J. Wu, Fuel, 2016, 177, 251-259.

19 D. Liu, W. Zhou and J. Wu, Adsorption, 2016, 22, 327-334.

20 D. Liu, W. Zhou and J. Wu, Chem. Eng. J., 2016, 284, 862-871.

21 R. Zhang, D. Shi, N. Liu, B. Chen, L. Wu, L. Wu and W. Yang, Catal. Today, 2015, 258, 17-27.

22 J. Li, Y. Yu, X. Li, W. Wang, G. Yu, S. Deng, J. Huang, B. Wang and Y. Wang, Appl. Catal., B, 2015, 172-173, 154-164.

23 X. Li, J. Li, G. Zhou, Y. Feng, Y. Wang, G. Yu, S. Deng, J. Huang and B. Wang, Appl. Catal., A, 2014, 481, 173-182.

24 L. Zhao, J. Gao, C. Xu and B. Shen, Fuel Process. Technol., 2011, 92, 414-420.

25 W. Z. Johan, C. Groen, S. Brouwer, S. J. Huynink, F. Kapteijn, J. A. Moulijn and J. Perez-Ramırez, J. Am. Chem. Soc., 2007, 129, 355-360.

26 A. Micke, M. Bulow and M. Kocirik, J. Phys. Chem., 1994, 98, 924-929.

27 Z. Zhu, G. Lu, Z. Zhang, Y. Guo, Y. Guo and Y. Wang, ACS Catal., 2013, 3, 1154-1164.

28 X. Yang, C. Gan, H. Xiong, L. Huang and X. Luo, RSC Adv., 2016, 6, 105737-105743.

29 Y.-Q. Deng, S.-F. Yin and C.-T. Au, Ind. Eng. Chem. Res., 2012, 51, 9492-9499.

30 Y. F. Yeong, A. Z. Abdullah, A. L. Ahmad and S. Bhatia, J. Membr. Sci., 2009, 341, 96-108.

31 R. Watanabe, T. Yokoi and T. Tatsumi, J. Colloid Interface Sci., 2011, 356, 434-441.

32 S. G. Fegan and B. M. Lowe, J. Chem. Soc., 1986, 82, 785-799. 33 N. Ren, J. Bronić, B. Subotić, X.-C. Lv, Z.-J. Yang and Y. Tang, Microporous Mesoporous Mater., 2011, 139, 197-206.

34 M. L. A. Catherine, A. Morris, R. M. Stroud, C. I. Merzbacher and D. R. Rolison, Science, 1999, 284, 622-624.

35 N. Tsunoji, S. Yuki, Y. Oumi, M. Sekikawa, Y. Sasaki, M. Sadakane and T. Sano, ACS Appl. Mater. Interfaces, 2015, 7, 24360-24369.

36 A. Murphy, Sol. Energy Mater. Sol. Cells, 2007, 91, 1326-1337. 